\title{
EFFECTS OF BASIC ABIOTIC FACTORS ON DEVELOPMENT OF THE EGGS AND ON SURVIVAL OF THE INFECTIVE LARVAE OF COMMON HELMINTHS OF SHEEP IN THE EXTERNAL ENVIRONMENT
}

\author{
EVA HOLASOVÃ, I. PAVLÁSEK and BOŽENA KOTRLÁ
}

\begin{abstract}
Institute of Parasitology, Czechoslovak Academy of Sciences, 37005 Ceské Budějovice
\end{abstract}

Received March 3, 1988

$A$ b s $t r a c t$

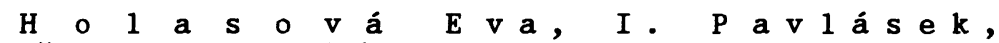
$B \circ z \check{z} n a k$ K on Development of the Eggs and on Survival of the Infective Larvae of Common Helminths of Sheep in the External Environment. Acta vet. Brno, 57, 1988: 153-168.

Development of the eggs of nematodes of the genera Strongyloides, Haemonchus, Trichostrongylus, Ostertagia and Chabertia to the infective larval stage was observed on $50 \times 50 \mathrm{~cm}$ grass-covered plots set out experimentally at monthly intervals during one year. The development was most rapid, taking 5 to 15 days, in May to September at mean monthly air temperatures of 15.6 to $23.8^{\circ} \mathrm{C}$. The infective larval stage was reached even at a mean monthly air temperature of $0.6^{\circ} \mathrm{C}$ and relative humidity of $76.3 \%$ in 65 days. No infective larvae were found in sheep faecal samples set out in November to February.

The survival time of the infective larvae of nematodes of the genera Haemonchus, Trichostrongylus, Ostertagia and Chabertia in the external environment was as long as 11 months. In summer months the larvae were destroyed in 2 to 4 months in consequence of a higher air temperature and lower relative humidity. Lower temperatures combined with higher relative humidity were withstood better: the first signs of destruction were observed after 5 to 7 months.

Repeated administration of Nilverm to naturally-infected sheep did not affect the rate of development of the larvae to the infective stage and probably did not even impair their viability.

Infective larvae, external environment, survival of infective larvae, NILVERM. 


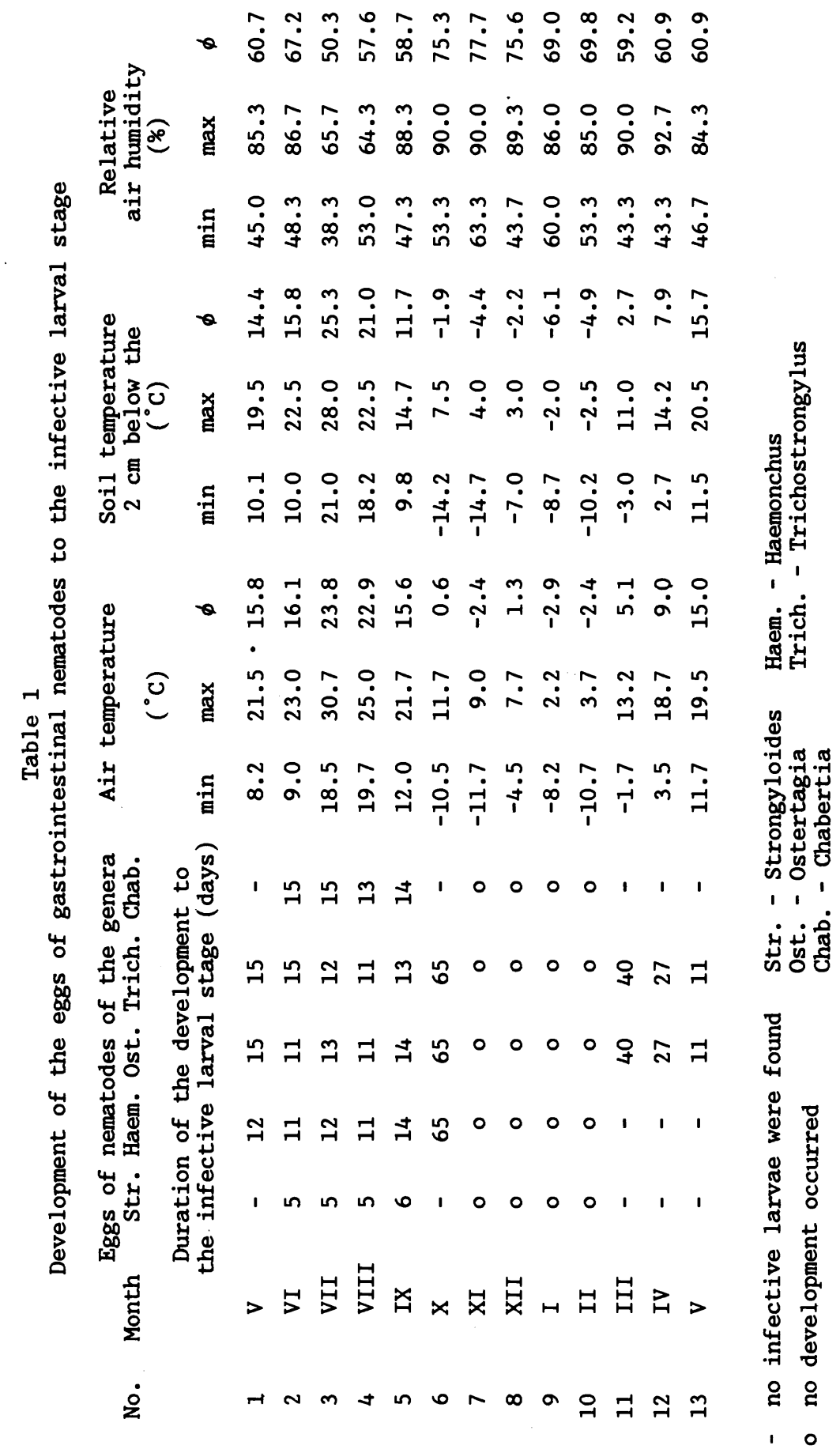


Parasitic nematodes of the sub-order Strongylata are characterized by a wide range of geographic distribution resulting from their ability to adapt themselves to various environmental factors. Recent adoption of intensive husbandry practices in animal and vegetable production has brought changes in the environmental conditions in which the development of parasites occurs. In spite of major progress achieved in the control of he1minths parasitic in the gastrointestinal tract of farm ruminants environmental factors including pasture, the density of animal populations in large herds and flocks and the use of dung as manure for growing various plants to be fed to animals are still much-feared sources of helminth infections. Further studies are therefore needed to investigate the development, survival and viability of the infective larvae of individual helmith species under various outdoor conditions.

The first comprehensive study on survival of the larval stages of parasitic worms on pasture in Czechoslovakia were reported by $\mathrm{E} \mathbf{r} \mathrm{h}$ a $\mathrm{r} \mathrm{d}$ ová (1961) who found that helminth larvae survived winter, the most resistant being those of the genera Ostertagia, Nematodirus and Chabertia; the infective larvae of these nematodes were viable even if the environmental temperature fell to $-30^{\circ} \mathrm{C}$. The bulk of relevant literature shows that in studies on ecological adaptation of the free-living stages of helminths it is necessary to consider the effects of both temperature and relative humidity. According to a number of writers the optimum temperature for the development of helminth larvae is 20 to $30^{\circ} \mathrm{C}$ ( $\mathrm{G} \mathrm{u} \mathrm{p} \mathrm{t} \mathrm{a}$ 1961; W a 11 a c e 1961), averaging $25^{\circ} \mathrm{C}$. T r a c (1975) reported that strongylate eggs developed in the temperature range between 4 to $5^{\circ} \mathrm{C}$ and 35 to $41^{\circ} \mathrm{C}$. The relative humidity required for development of the eggs ranges reportedly between 20 and $50 \%$. B a s h i r o v (1979) found that eggs of the genera Ostertagia and Trichostrongylus survived at -16 and $-25^{\circ} \mathrm{C}$ and that in April the larvae developed within one month at an average month temperature of $6.4^{\circ} \mathrm{C}$ and were, according to his view, the source of infection of sheep and cattle in May or July.

Development of a new helminth infection is possible only where infective larvae are present. Therefore the survival and duration of viability of the infective larvae of most pathogenic helminth species continues to be studied from various points of view. Although the results published so far have often been contradictory, the evidence thus obtained contributes to a better understanding of the principles underlying the development and survival of the free-living stages of parasites in the external environment.

The present study was designed to assess the effects of basic ecological factors on the rate of development of the infective larvae of the he1minths occurring most frequently in our large herds of cattle and flocks of sheep and test their survival during a one-year period. Consideration was also given to NILVERM, an anthelmintic commonly used to treat naturally-infected animals, as to its effects on the course of development of the eggs to the infective larval stage.

\section{Materials and Methods}

Effects of basic abiotic factors on the development of nematodes of the genera Strongyloides, Haemonchus, Ostertagia, Trichostrongylus and Chabertia were investigated during one year. Values of some meteorological elements (Fig. 1) were obtained from a climatological station about $8 \mathrm{~km}$ distant from the observation place and were used to supplement our own observations on air temperature, relative humidity and soil temperature conducted on the spot (Table 1). 
1. Methods used to assess the rate of development of the eggs to the infective larval stage and the survival of the infective larvae in dependence on environmental outdoor conditions

The study was carried out on a field workplace of the Parasitological Institute of the Czechoslovak Academy of Sciences at $425 \mathrm{~m}$ above sea level. At monthly intervals sheep faecal pellets positive for the presence of eggs of the aforementioned helminths were placed in $1 \mathrm{~kg}$ quantities in the middle of small $(50 \times 50 \mathrm{~cm})$ experimental plots to occupy in each plot a circular area of about $20 \mathrm{~cm}$ in diameter. In this way a total of $13 \mathrm{ex}-$ perimental plots were set out on sand-and-clay soil with grass allowed to reach maximally $10 \mathrm{~cm}$ in height.

From each plot sheep faecal samples of circa 3 to $5 \mathrm{~g}$ were collected daily till the first infective larvae appeared. Their survival and morphology were investigated at monthly intervals during the following period.

2. Methods used to investigate the effects of administration of NILVERM (Bioveta, Czechoslovakia) on the rate of development of the eggs till the larval infective stage in sheep naturally infected with nematodes of the genera Trichostrongylus, Ostertagia, Chabertia, Strongyloides and Haemonchus

A total of 7 sheep ( 3 males and 4 females) were included in the experiment. Faecal samples were taken from all of them repeatedly and examined by culture before NILVERM administration. The males were injected with NILVERM at the dose of $4 \mathrm{ml}$ per animal and the ewes served as controls. Two males in which nematode eggs reappeared in the faeces were treated repeatedly with the same dose of NILVERM, one on day 28 and then again on day 43 and the other one on day 81 after the first treatment. All the sheep were faeces-sampled individually from the rectum three times a week throughout the observation period of 132 days.

3. Methods used for examination and culture of sheep faecal samples

a Coprological method based on flotation and centrifugation according to B $\mathrm{r}$ e z a (1957) using $1 \mathrm{~g}$ faeces.

$b$ Infective larvae of the helminths were obtained from the faeces on the individual experimental plots by a modification of the $B$ a $\mathrm{r} m \mathrm{~m} n \mathrm{n}$ technique.

c To test the effects of NILVERM on the rate of development from the eggs to the infective larval stage, the faeces from naturally-infected sheep treated with NILVERM were incubated under laboratory conditions at $25^{\circ} \mathrm{C}$ and $100 \%$ relative humidity. Infective larvae were recovered by a modification of the Baermann technique.

\section{Results}

1. The rate of development of helminths of the sub-order Strongylata from the eggs to the infective larval stage

The rate of development from the eggs to the infective larval stage in dependence on the air and soil temperatures and relative humidity is shown in Table 1 . It can be seen 


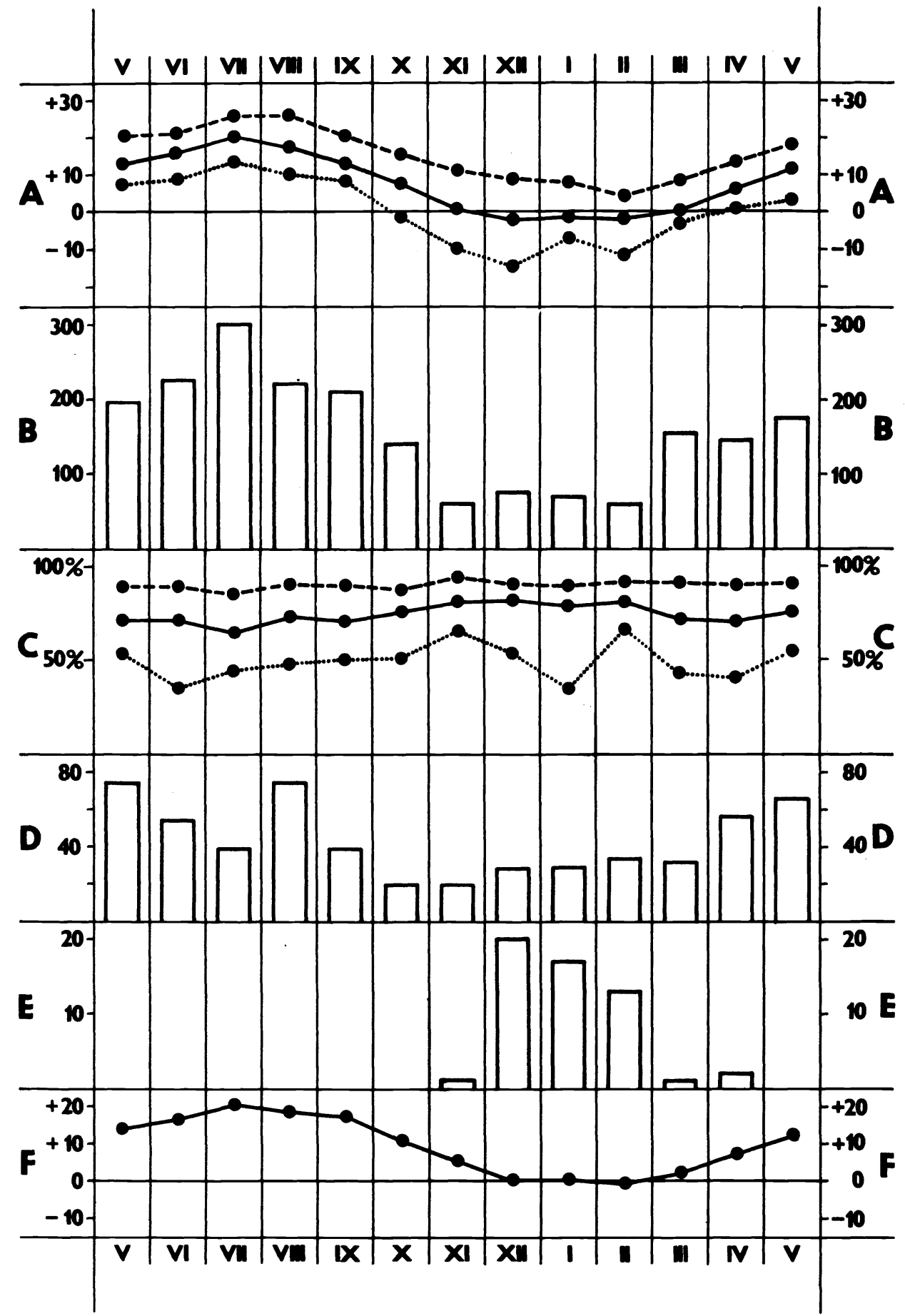

Fig. 1. Some of the basic meteorological data during the experiment 
that in May to September the development to the infective larval stage occurred most rapidly (taking 5 to 7 days) in S. papillosus. Larvae of the remaining species ( $\mathrm{H}$. contortus, Trichostrongylus spp., Ostertagia spp. and C. ovina) began to hatch on days 3 to 4 and 2 nd stage larvae were observed on days 6 to 8 . The first infective larvae ( $\underline{H}$. contortus and Trichostrongylus spp.) developed 11 to 15 days after the experiment was started. During this period the mean monthly temperature ranged from $15.6^{\circ} \mathrm{C}$ (September) to $23.8^{\circ} \mathrm{C}$ (July) and the relative humidity ranged from $50.3 \%$ (July) to $67.2 \%$ (June).

In the experiment set up in October the first solitary larvae hatched on day 20 and the infective larvae ( $\mathrm{H}$. contortus, Ostertagia spp. and Trichostrongylus spp.) were first observed on day 65. Almost half of the embryonated eggs did not develop any further. The mean air temperature was $0.6^{\circ} \mathrm{C}$ (ranging from -10.5 to $11.7^{\circ} \mathrm{C}$ ) and the mean relative humidity was $75.3 \%$.

In the experiment set up in November some signs of embryonation were observed in $\mathrm{H}$. contortus, Ostertagia spp., Trichostrongylus spp. and C. ovina. Larvae within the eggs (some of them motile) were observed very rarely on day 12. The process of embryonation occurred at the time that the mean daily temperature ranged between 3.2 and $9.0^{\circ} \mathrm{C}$, which lasted only four days (days 8 to 11 after the experiment was started). On the remaining days the air temperature was low, falling below zero. The mean air temperature was $-2.4^{\circ} \mathrm{C}$ and the mean relative humidity was $77.7 \%$.

Fig. 1. Values of some basic meteorological elements

Abscissa: months of the year

Ordinate: A - air temperature $\left({ }^{\circ} \mathrm{C}\right)$

- mean monthly air temperature $\left({ }^{\circ} \mathrm{C}\right)$

..... minimum monthly air temperature $\left({ }^{\circ} \mathrm{C}\right)$

B - hours of solar radiation

C - relative humidity (\%)

mean monthly relative humidity (\%)

-..- maximum monthly relative humidity $(\%)$

..... minimum monthly relative humidity $(\%)$

D - tota1 precipitation ( $\mathrm{mm}$ )

E - No. days with snow cover

F - mean monthly soil temperature measured $2 \mathrm{~cm}$ beneath the soil surface $\left({ }^{\circ} \mathrm{C}\right)$ 
In the experiment set up in December the presence of larvae was found in 50\% of the eggs on day 4. These larvae were non-motile and did not develop any further. The mean air temperature was $1.3^{\circ} \mathrm{C}$ and the mean relative humidity was $75.6 \%$.

In the experiment set up in January and February daily examination of the faecal samples revealed no development of the larvae within the eggs during the 30-day observation period. The mean air temperatures were -2.9 and $-2.4^{\circ} \mathrm{C}$ and the relative air humidity values were 69 and $69.8 \%$, respectively. In the four last-mentioned months (November to February) no infective larvae were found at the following monthly examinations which were carried out till June.

In the experiment set up in March the first signs of embryonation were observed on day 5. Beginning day 9 hathing occurred sporadically and the first infective larvae of Trichostrongylus spp. and Ostertagia spp. appeared on day 40 after the start of the experiment.

In the experiment set up in April embryonation began on day 3 and the first infective larvae (Ostertagia spp.) were observed on day 27. The mean air temperature was $9^{\circ} \mathrm{C}$ and the relative humidity was $60.9 \%$.

In the experiment set up in May the first infective larvae of Trichostrongylus spp. were found on day 11, which is in keeping with the observations made in May of the preceding year.

2. Viability and survival of the infective larvae

As can be seen from Table 2 the infective larvae of $\underline{H}$. contortus, Trichostrongylus spp. and Ostertagia spp. from experimental plots (set out in May and June) showed reduced motility and the first vacuoles in their bodies as early as in September. In $\mathrm{C}$. ovina infective larvae, vacuoles were very rare. Although the infective larvae gradually died, examination of the faeces from these plots revealed specimens of the infective larval stage of Trichostrongylus spp. and Ostertagia spp. up to April of the following year (i.e. after 11 months including overwintering). 


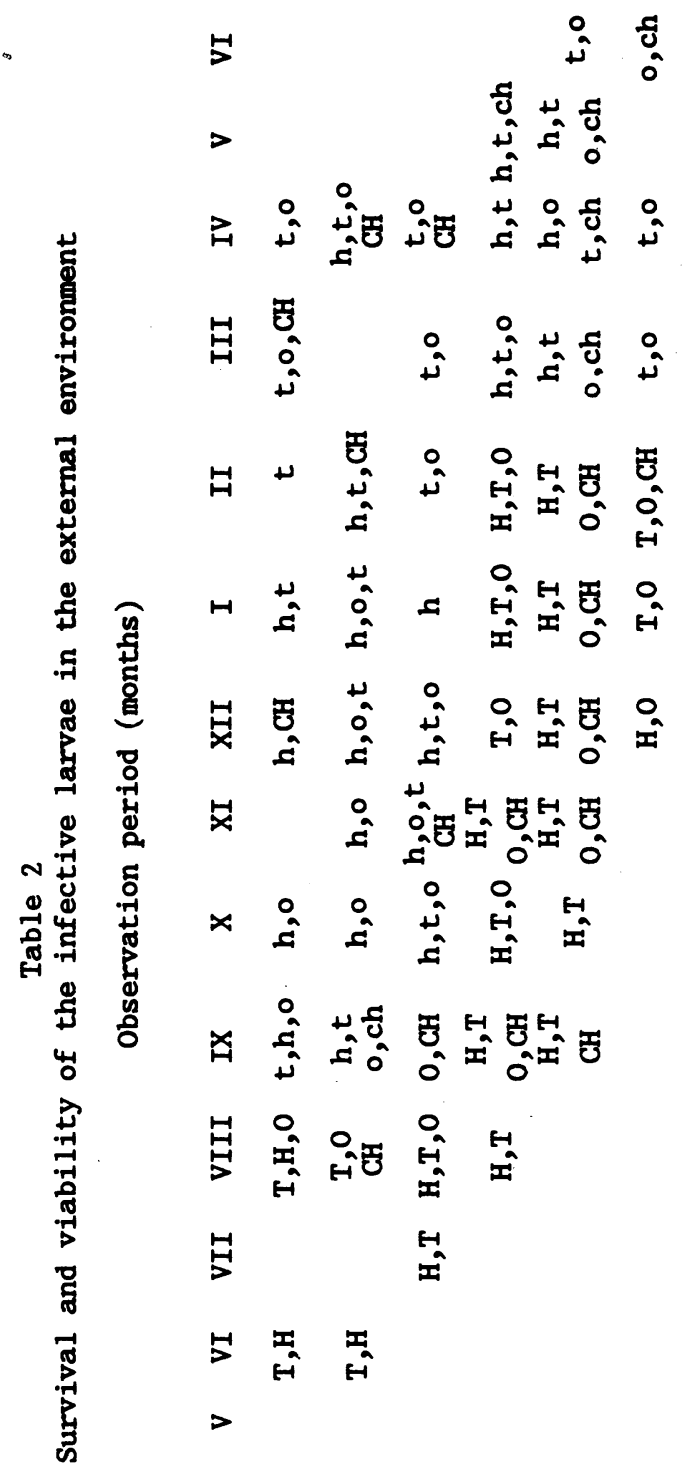

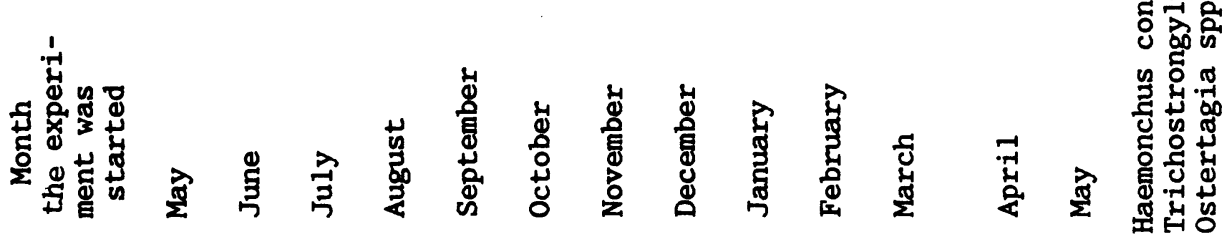

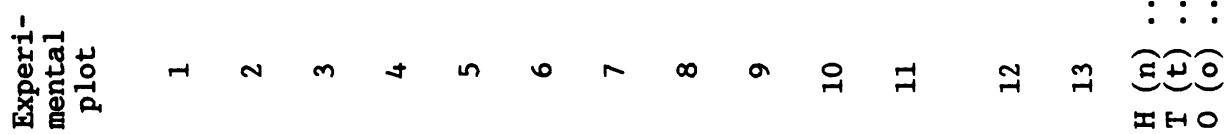


On experimental plots 4 to 6, set out in August to October, infective larvae with vacuoles and reduced motility were found 5 to 7 months after the start of the experiment (i.e. ater overwintering of the infective larvae).

On experimental plots 11 to 13 , set out in March to May of the following year, development and survival of the infective larvae were observed in Trichostrongylus spp. and Ostertagia spp.

3. Effect of NILVERM administration on the course of development of the eggs

The results of cultivation up to the infective larval stage of sheep faeces containing eggs of five nematode species before treatment with NILVERM are shown in Table 3 . The most rapid development of the infective larvae (on day 4) was shown by $S$. papillosus. The first infective larvae of Trichostrongylus spp., C. ovina, Ostertagia spp. and $\underline{H}$. contortus in the faecal samples were observed on days $\overline{5}$, $\overline{8,10 \text { and }} 11$ of culture, respectively.

Faecal samples from the three NILVERM-treated sheep contained S. papillosus, Trichostrongylus spp. and $\underline{H}$. contortus eggs on day 2 after administration. Examination on the 3rd post-treatment day yielded negative results. On day 6, however, sheep No. 2 was found to excrete Trichostrongylus spp. and Trichuris ovis eggs and did so for 28 days.

Sheep No. 3 was found to excrete Trichostrongylus spp., Ostertagia spp., S. papillosus and C. ovina eggs 70 days after NILVERM administration. Sheep No. 1 showed no evidence of nematodes after a single dose of NILVERM till the end of the 132-day observation period.

Sheep No. 2 received a second $4 \mathrm{ml}$ dose of NILVERM 28 days after the first treatment and began to excrete $S$. papillosus, Trichostrongylus spp., Ostertagia spp., $\underline{\underline{H} .}$ contortus, T. ovis and Capillaria sp. eggs 6 days later. After being treated with NILVERM for a third time (43 days after the first administration and 15 days after the second administration), this animal excreted Trichostrongylus spp., Ostertagia spp., $\mathrm{H}$. contortus, $\underline{\mathrm{C} \text {. ovina and }}$ 


$$
\begin{aligned}
& \Rightarrow+++++ \\
& 0++++1
\end{aligned}
$$
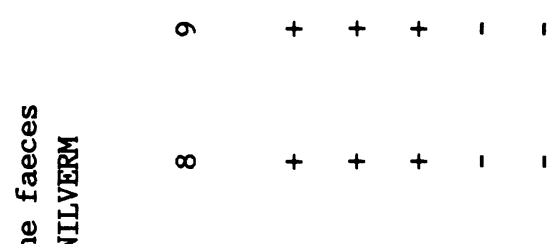

물

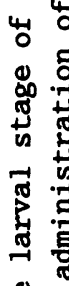

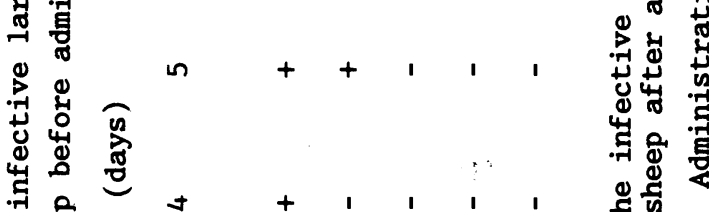

ఫ

오 웅

돈

5

if

䇋

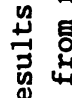

Q

运是

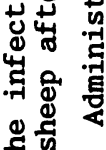

疍 $1++++1+$

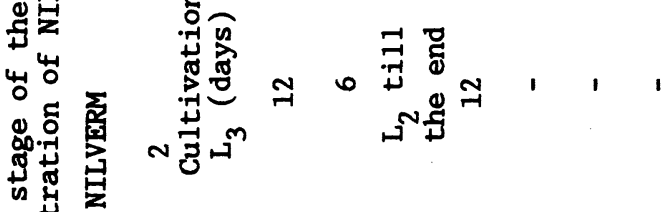

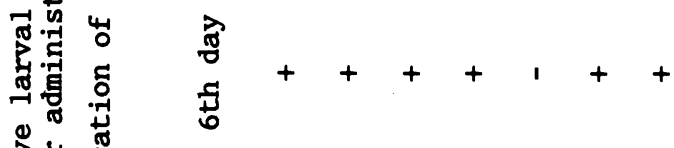

웜

号景

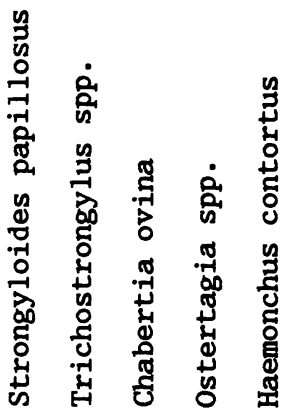

ธี

范

군

उ

出壳

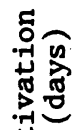

उુำ

超 $1+1,1,1+$

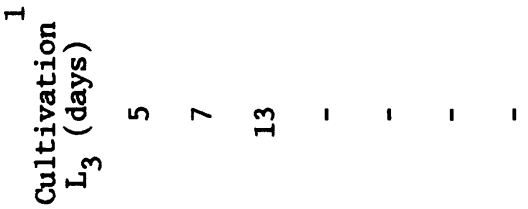

急

ัำ

$\stackrel{+}{\stackrel{0}{\pi}}$

龺 
T. ovis eggs from 2 to 27 days after the third treatment. It was only from this time onward (i.e. beginning 71,43 and 28 days after the first, second and third treatments, respectively) that no eggs were revealed in the faeces of this sheep till the end of the observation period.

Control untreated ewes excreted eggs of nematodes of the genera Strongyloides, Trichostrongylus, Ostertagia, Haemonchus, Trichuris and Chabertia throughout the observation period.

The effect of NILVERM administration on the rate of development of the eggs at $25^{\circ} \mathrm{C}$ and $100 \%$ relative humidity under laboratory conditions is shown in Table 4. On culture of the faecal samples collected from the three NILVERM-treated sheep $24 \mathrm{~h}$ after the first administration infective larvae of $\underline{S}$. papillosus, Trichostrongylus spp. and $\mathrm{H}$. contortus were first observed on days 5,7 and 13, respectively. On culture of the faeces (containing eggs of nematodes of the genera Trichostrongylus and Trichuris collected from sheep No. 2 on day 6 after the first NILVERM administration the infective larval stage was reached only by Trichostrongylus spp. in 8 days.

The faeces from the same animal containing eggs of 6 nematode species (see above) was cultured again on day 6 after the second NILVERM administration. Infective larvae of Trichostrongylus spp. were first observed on day 6 and those of S. papillosus and Ostertagia spp. on day 12 . $\mathrm{H}$. contortus larvae. were still in the second stage 13 days after the cultivation was started.

On culture of a positive faecal sample collected from the same animal $24 \mathrm{~h}$ after the third NILVERM administration infective larvae of Trichostrongylus spp., Ostertagia spp. and $\mathrm{H}$. contortus were first observed on day 7 and those of C. ovina on day 8.

\section{Discussion}

Helminth infections continue to be a problem particularly under intensive husbandry practices because most 3rd stage (infective) larvae are able to survive under outdoor conditions. Investigations into the biology and development of 
their pre-parasitic stages under the present environmental conditions are therefore essential for organization of optimal preventive measures. Although a number of relevant reports have been published, the results are often contradictory. To be effective, any helminth control program must therefore take into account the actual environmental conditions in which the development of gastrointestinal nematodes takes place.

From our study on the rate of development of the eggs of five species of gastrointestinal nematodes of ruminants during a 13-month period (May to May) it appears that the infective larval stage was reached most rapidly, in 5 days, by $S$. papillosus and in 11 days by $\underline{H}$. contortus and Trichostrongylus spp. According to $G \circ 1 \mathrm{~d} \mathrm{~b}$ e $\mathrm{g}$ and $\mathrm{L} \mathrm{u} \mathrm{c} \mathrm{k} \mathrm{e} \mathrm{r} \mathrm{(1963)} \mathrm{the} \mathrm{development} \mathrm{of} \mathrm{infective} \mathrm{larvae}$ from $H$. contortus eggs takes 7 to 21 days at 15 to $16^{\circ} \mathrm{C}$, according to $\mathrm{P} u \mathrm{~s}$ t $\mathrm{O}$ $\mathrm{j}$ (1970) it takes 7 to 8 days at the mean air temperature of 15.1 to $16.7^{\circ} \mathrm{C}$. In keeping with a number of other writers we found that development of the eggs to the infective larval stage became longer as the air temperature decreased. Thus $M \circ r g$ a $n$ et al. (1951), fo example, found that Ostertagia circumcinta eggs developed to the infective larval stage at $5{ }^{\circ} \mathrm{C}$ and $\mathrm{S} h \mathrm{u} \mathrm{m}$ a k o v i c h et al. (1968) reported that helminth eggs developed to the infective larval stage at $10^{\circ} \mathrm{C}$ in 12 to 31 days.

In our study the development of Ostertagia spp. and Trichostrongylus spp. eggs proceeded till the infective larval stage not only at the mean air temperature of $5.1^{\circ} \mathrm{C}$ (taking 40 days but also at the mean temperature of $0.6^{\circ} \mathrm{C}$ and at the relative humidity of $75.3 \%$. Under these outdoor conditions $\mathrm{H}$. contortus and Ostertagia spp. infective larvae were first detected on day 65 .

Larvae did not develop in the period November to February at which time the mean air temperature fell below $-2.0^{\circ} \mathrm{C}$. From our results it appears that under these conditions helminth eggs of the genera Haemonchus, Trichostrongylus and Chabertia are unable to develop and lose their viability at temperatures below zero. Our findings are in keeping with the observations of $P$ e $s, s \quad n$ (1974) and T. $r$ a č (1975) but differ from those of B a s h i r o v (1979) who reported that eggs of the genera Ostertagia and Trichostrongylus survived at -16.0 to -25.0 C. From our results it also appears that under our 
conditions development of the eggs to the infective larval stage is most rapid in May to September, i.e. during the grazing season.

In our study the infective larvae survived under outdoor conditions for as many as 11 months, depending on the period during which the faeces were put on experimental plots. High air temperatures in combination with a low relative humidity in summer led to the destruction and vacuolization of infective larvae in as few as 2 to 4 months. On the other hand, the infective larvae were able to withstand lower temperatures combined with a high relative humidity much better, showing the first signs of vacuolization after 5 to 7 months. Similar observations were reported by $W$ i 1$1 \mathrm{i} \mathrm{a} \mathrm{m} \mathrm{s}$ and $\mathrm{B}$ i $1 \mathrm{k}$ o $\mathrm{vich}$ (1971) and $\mathrm{P}$ e $\mathrm{s}$ s o (1974). The shortest survival times of infective larvae under our outdoor conditions were recorded for $\mathrm{H}$. contortus ( 8 to 9 months) followed by $\mathrm{C}$. ovina (10 months). Infective larvae of Trichostrongylus spp. and Ostertagia spp. survived for 11 months.

To combat helminth infections of cattle and sheep, many anthelmintics have been used under a variety of chemotherapeutic regimens. From a number of studies it appears that their effects are often short-lived, in consequence of which repeated treatment has been frequently recommended ( $K \circ \mathrm{t} r 1$ á and $K \circ \check{z} d \circ \check{n}$ 1981). Up to now the effects of maybe inadequately large and repeated doses of anthelmintics on development of the eggs to the infective larval stage remain undisclosed. Our preliminary results suggest that repeated administration of NILVERM to naturally-infected sheep had no marked effect on the rate of development of the eggs to the infective larval stage and presumably did not impair the viability of infective larvae either.

Our findings are of value to a better understanding of the spread of helminth infections. The ability of the infective larvae to survive and overwinter in the external environment, practically unimpaired development of the eggs to the infective larval stage without loss of infectivity after repeated anthelmintic treatment and particularly rapid development to the infective larval stage during the grazing season are responsible for contamination of the grassland throughout the year, making it the source of helminth infection of young animals. 
Vliv základních abiotických faktorů na vývoj vajiček a schopnost přežívání invazních larev významných druhů helmintů ovcí ve vnějším prostředí

Vývoj vajíček hlístic rodů Strongyloides, Haemonchus, Trichostrongylus, Ostertagia a Chabertia do vzniku invazních larev byl sledován $\mathrm{v}$ průběhu jednoho roku $\mathrm{v}$ měsíčních intervalech na experimentálně zakládaných travních plochách o rozměrech 50 × $50 \mathrm{~cm}$. Nejrychleji, 5 - 15 dnů, probíhal vývoj $u$ jednotlivých druhů $v$ měsících květnu až zárí při průměrné teplotě vzduchu od $15,6{ }^{\circ} \mathrm{C}-23,8{ }^{\circ} \mathrm{C}$. Vývoj larev do invazního stadia probíhal po dobu 65 dnů i při průměrné teplotě vzduchu $0,6{ }^{\circ} \mathrm{C}$ a relativní vlhkosti vzduchu 76,3 \%. V období měsíců listopad až únor jsme žádné invazní larvy $\mathrm{v}$ zakládaných vzorcích trusu nenalezli.

Ve vnějším prostředí přežívaly až po dobu 11 měsíců invazní larvy hlístic rodů Haemonchus, Trichostrongylus, Ostertagia a Chabertia. V letním období dochází vlivem vyšší teploty a nižší relativní vlhkosti vzduchu $k$ destrukci larev během 2 - 4 měsíců. Nižší teploty $s$ vyšší relativní vlhkostí vzduchu snášejí invazní larvy lépe. První známky destrukce byly pozorovány po 5 - 7 měsících.

Opakované podávání NILVERMU spontánně invadovaným ovcím výrazně neovlivnilo rychlost vývoje larev do invazního stadia a pravděpodobně nedochází ani $\mathrm{k}$ narušení jejich životaschopnosti.

Влияние основных абиотических Факторов на развитие яичек и способность выживания инвазионных личинок важных видов гельминтов овец и крупного рогатого скота во внешней среде

Развитие яичек нематод рода Strongyloides, Haemonchus, Trichostrongylus, Ostertagie и Chabertia до возникновения инвазионных личинок исследовали в течение одного года с месячными интервалами на экспериментально созданном травянистом покрове размером 50 × 50 цм. Быстрее всего, пять - пятнадцать суток, протекало развитие отдельных видов с мая по сентябрь при средней температуре воздуха $15,6{ }^{\circ} \mathrm{C}$ - $23,8^{\circ}$. Развитие личинок до инвазионной стадии про- 
текало 65 суток даже при средней температуре воздуха $0,6{ }^{\circ} \mathrm{C}$ и отностительной влажности воздуха $76,3 \%$. С ноября по февраль никаких инвазионных личинок в образцах кала нами не было обнаружено.

Во внешней среде выживали до 11 месяцев инвазионные личинки нематод рода Haemonchus, Trichostrongylus, Ostertagia и Chabertia. В летний период под воздействием более высокой температуры и более низкой относительной влажности воздуха происходит в течение 2 - 4 месяцев деструкция личинок. Более низкую температуру $c$ более высокой относительной влажностью инвазионные личинки переносят лучше. Первые признаки деструкции наблюдались спустя 5 - 7 месяцев.

Повторная дача НИЛЬВЕРМА спонтанно инвадированным овцам не оказала сүщественного влияния на скорость развития личинок до инвазионной стадии и, по всей вероятности, не нарушается их жизнеспособность.

\section{References}

BASHIROV, R.G.: Survival of trichostrongylid ova in bovine faeces on pastures. Trudy Belorusskogo Nauchno- Issledovatelskogo Instituta Experimentalnoj Veterinarii, 1979: 93-95.

BREZA, M.: Niekol'ko praktických poznatkov a námetov $k$ helmintokoprologickej diagnostike. Helminthologia, 1957: 57-63.

ERHARDOVÁ, B.: Výsledky laboratornich a terénních pokusů o přeživání larválních stadii cizopasných červi jako podklad pro prevenci některých pastevnich parazitóz. Závěrečná zpráva, Paư ČSAV Praha, 1961: p. 35.

GOLDBERG, A. - LUCKER, J.T.: Survival on pature of larvae of gastrointestinal nematodes of cattle. III. Fal contamination. J. Parasit., 49, 1963: 435-442.

GUPTA, S.P.: The effects of temperature on the survival and development of the free-living stages of Trichostrongylus retortaeformis Zeder ( $\mathrm{Ne}-$ matoda). Canad. J. Zoo1., 39, 1961: 47-53.

HULINSKÁ, I.: Die Determinationsmerkmale der Invasionslarven bei Schafdarmhelminthen. Acta sci. natur. Acad. Sci. bohemoslov. Brno, 3, 1969: $1-35$.

KOTRLÁ, B. - KOŽDOŇ, O.: Opakovaně prováděná dehelmintizace a jeji vliv na prüběh přirozené invaze ovcí. Vet. med., 26, 1981: 497-504.

MORGAN, D.O. - PARNELL, I.V. - RAYSKI, C.: The seasonal variation in the worm burden of Scottish hill sheep. J. Helminth., 25, 1951: 177-212.

PERSSON, L.: Studies on the bionomics of eggs and infective larvae of Ostertagia ostertagi and Cooperia oncophora in soil. Zentb1. Vet. Med., 21, 1974: 318-328. 
PUSTOVOJ, I.F.: Strongyljatozy piščevaritelnogo trakta ovec Tadžiskoj SSR. Thesis, VIGIS. Author s summary, Moskva, 1970: 1-45.

SHUMAKOVICH, E.E.: Gelmintozy žvačnych životnych. Moskva, 1968: p. 389.

TRAČ, V.N.: Strongylata žvačnych životnych. Ekologija i biologija. Thesis, VIGIS. Author's summary, Moskva, 1975: 1-55.

WALLACE, H.R.: The bionomics of the free-living stages of zooparasitic and phytoparasitic nematodes. A critical survey. (Review Article) Helminth. Abstract, 30, 1961: 1/22.

WILLIAMS, J.G. - BILKOVICH, F.F.: Development and survival of infective larvae of the cattle nematode, Ostertagia ostertagi. J. Parasitol., 57, 1971: 327-338. 